\title{
Soil microbiota: Influence of different land use patterns and soil management factors at Villavicencio Oxisol, East Colombia
}

Microbiota del suelo: influencia de diferentes patrones de uso de la tierra y factores de manejo del suelo en un Oxisol de Villavicencio, Oriente de Colombia

\author{
Amanda Silva-Parra, Ángela M. Mogollón-Ortiz y Hernando Delgado-Huertas
}

\begin{abstract}
The soil microbiota is a biological indicator. The impact of four different land use patterns: Secondary forest (T1), rice monoculture (T2), pineapple monoculture (T3) and agroforestry system of Theobroma cacao associated with Acacia mangium (T4) at different distances: 0-10 cm (D1), 10-20 cm (D2), 20-30 cm (D3), $3040 \mathrm{~cm}$ (D4) and 40-50 cm (D5) on counts of Colony Forming Units (CFUs) of fungi, bacteria, actinobacteria were tested in an Oxisol of Villavicencio, Orinoquia, East Colombia. An unrestricted random design was applied. More number of CFUs of soil bacteria, fungi and actinobacteria were recorded in secondary forest (T1) at all the distances from the root surface when compared to the other treatments. However, a similar trend was observed for counts of CFUs of soil fungi and bacteria in secondary forest (T1) at (D4) and (D5) distances from the root surface compared with agroforestry system (T4) at all distances from the root surface $(\mathrm{P} \leq 0.05)$. Meanwhile that there was similarity in number of CFUs of soil actinobacteria between secondary forest (T1) and agroforestry system (T4) at all the distances ( $\mathrm{P} \geq 0.05)$. The least count of CFUs of soil microbiota was recorded in pineapple monoculture (T3) at all the distances from the root surface $(\mathrm{P} \leq 0.05)$.
\end{abstract}

Key words. Agroforestry system. Diversity. Microorganism. Monoculture.

\section{Resumen}

La microbiota del suelo es un indicador biológico. Se investigó el impacto de diferentes patrones de usos del suelo: bosque secundario (T1), monocultivo de arroz (T2), monocultivo de piña (T3) y sistema agroforestal de Theobroma cacao asociado con Acacia mangium (T4) a diferentes distancias desde la superficie de la raíz: 0-10 $\mathrm{cm}$ (D1), 10-20 cm (D2), 20-30 cm (D3), 30-40 cm (D4) y 40-50 cm (D5) en el conteo de Unidades Formadoras de Colonias UFCs de hongos, bacterias y actinobacterias en un Oxisol de Villavicencio, Orinoquia, Oriente de Colombia. Se aplicó un diseño irrestrictamente al azar. Un mayor número de UFCs de bacterias, hongos, y actinobacterias del suelo fueron encontrados en el bosque secundario (T1) en todas las distancias desde la superficie de la raíz comparado con los otros tratamientos; sin embargo, una similar tendencia fue observada para los conteos de UFCs de bacterias y hongos en el bosque secundario (T1) en las distancias (D4) y (D5) desde la superficie de la raíz comparado con el sistema agroforestal (T4) en todas las distancias desde la superficie de la raíz $(\mathrm{P} \leq 0.05)$. Mientras tanto hubo similaridad en el número de UFCs de actinobacterias entre bosque secundario (T1) y sistema agroforestal (T4) en todas las distancias ( $\mathrm{P} \geq 0.05)$. Los más bajos conteos de UFCs de la microbiota del suelo fueron reportados en el monocultivo de piña (T3) en todas las distancias desde la superficie de la raíz $(\mathrm{P} \leq 0.05)$.

Palabras claves. Diversidad. Microorganismos. Monocultivo. Sistema agroforestal. 


\section{Introduction}

The rhizosphere may be defined as that portion the soil zone that surrounds and is influenced by the roots of plants (Paul and Clark 1996). The adoption of different land use management can have negative or positive effects on the rhizosphere soil microbiota (Barrios 2007, Notaro et al. 2008). The number of Colony Forming Units (CFUs) of bacteria, fungi, and actinobacteria in the rhizosphere may largely determine microsite occupancy, depending of the distances from the root surface (Kent and Triplett 2002).

The major cause of changes in forest use in Villavicencio is land clearing for monoculture, mainly rice monoculture, than according to Delgado et al. (2009) influenced soil microbiota. Several research have examined the effects of soil management practices on number of CFUs of rhizosphere soil microbiota in different land use type (Balota et al. 2003, Bausenwein et al. 2008, Jangid et al. 2008, Ceja-Navarro et al. 2010, Prevost-Boure et al. 2011); monoculture is one of the most significant anthropogenic activities that alter soil biological properties and processes (Brussaard et al. 2007, Jangid et al. 2008) due to that conventional tillage can affect above ground residues content (Alvear et al. 2005, Roger-Estrade et al. 2010, Mathew et al. 2012).

Agroforestry systems appear to be a good alternative as land use patterns for increase soil microbiota in the humid tropics, due to high litter production and increases in soil organic matter, the large root system of trees in agroforestry systems potentially accumulates nutrients from a large volume of soil, whereas fallen litter concentrates nutrients near the soil surface (Reis et al. 2007, Notaro et al. 2008). The return of residue to the field in agroforestry systems is a useful cultural practice to improve both soil fertility and soil organic carbohydrate storage ensuring the survival of soil microorganisms (Barreto et al. 2008, Notaro et al. 2008, Paudel et al. 2012).

Consequently, fungi, bacteria and actinobacteria are the most sensitive and rapid indicators of soil perturbations due to land use changes. In this sense, a quantitative description of soil microbial population has great interest as a potential tool for soil quality evaluation (Brussaard et al. 2007).

We hypothesized that soil management practices in different land use patterns would result in changes on rhizosphere soil microbiota, that can provide important information for sustainable production systems in tropical regions of Colombia.

In this context, the aims of this research was to estimate the effect of different land use patterns: Secondary forest (T1), rice monoculture (T2), pineapple monoculture (T3) and agroforestry system of Theobroma cacao associated with Acacia mangium (T4), with different soil management factors and at different distances from the root surface on number of Colony Forming Units (CFUs) of soil rhizosphere fungi, bacteria and actinobacteria in an Oxisol of Villavicencio, Orinoquia, Colombia East.

\section{Materials and methods}

The study site is located between the coordinate $4^{\circ} 04$ ' $47^{\prime \prime} \mathrm{N}$ and $73^{\circ} 35^{\prime} 17^{\prime \prime} \mathrm{W}$. The experiment was conducted on an Oxisol in a humid tropics zone of Villavicencio, Orinoquia, Colombia East, specifically in Barcelona farm, Unillanos University (Figure 1). The temperature is from 28 to $30^{\circ} \mathrm{C}$ with long dry season (Igac 2004) and average annual rainfall of 3,663 $\mathrm{mm}$. Average altitude of $525 \mathrm{~m}$. a.s.l. Relative humidity of $65 \%$.

The work was developed in an unrestricted random design. The experimental design consisted of four treatments of land use patterns (Figure 2): Secondary forest system (T1): This area contained one ha, this system had been maintained for nearly 10 years and although there had been no management, high influence of above ground residue input. Rice monoculture (T2): This area contained 0.5 ha, with more than 5 years grown, conventional tillage was conducted by disking $(0-20 \mathrm{~cm})$ after harvest, followed by chiselplowing $(0-20 \mathrm{~cm})$, a second disking, and ridging, 


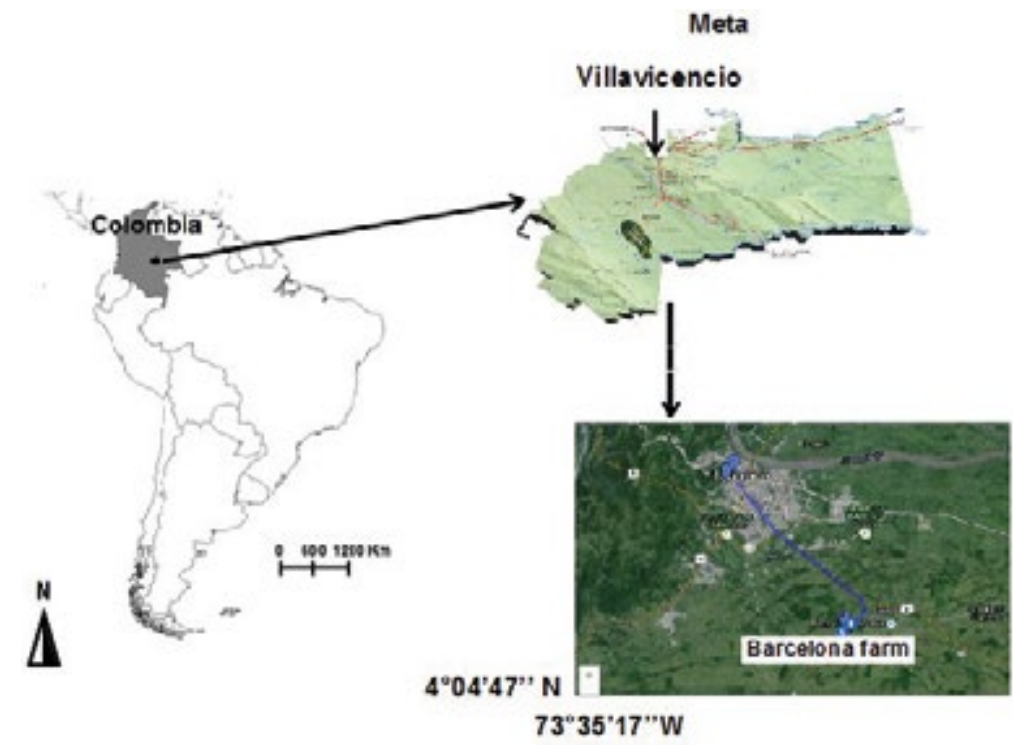

Figura 1. Close photo of location of the studied land use patterns located in Barcelona farm, Unillanos University, Villavicencio city, Meta state, Colombia.

reduced inputs from above-ground residues. Pineapple monoculture (T3): This area corresponds to a small area of investigation, which contained $<0.5$ ha, with 1 year grown. Conventional tillage, reduced inputs from above ground residues. Agroforestry system of Theobroma cacao associated with Acacia mangium (T4): This area contained one ha, with 5 years grown, the area was managed with reduced tillage, and it was made only loosening the floor to make holes for planting of the trees, with high influence of above ground residue input.

All systems exhibit the same agroecological conditions (Figure 2).

Three soil samples from each study system were collected in dry season along a transect at regular intervals. Soil sampling was done up to a depth of $20 \mathrm{~cm}$ and were collected from five different points (distances from the root surface), 0-10 cm (D1), 10- 20 cm (D2), 20-30 cm (D3), 30-40 cm (D4), 40-50 cm (D5). A composite sample for each depth was made by thoroughly mixing three samples in a given site and triplicate of subsamples were considered for further analysis.


Figura 2. Land use patterns: a) Secondary forest (T1).

b) Rice monoculture (T2). c) Pineapple monoculture (T3). d) Agroforestry system of Theobroma cacao associated with Acacia mangium (T4). 
A total of 60 samples $(4$ systems $\times 5$ distances from the root surface $\mathrm{x} 3$ replicates) were analysed.

The samples underwent serial dilution technique and pour plate method to detect the number of CFUs of bacteria, fungi and actinobacteria (Alexander 1982). Ten grams of soil were shaken with $90 \mathrm{ml}$ of distilled water. From this suspension, the serial solution was prepared. An amount of $0.5 \mathrm{ml}$ of the serially diluted solution was plated on agar by the pour plate technique (Alexander 1982). Three main types of agar were used. Nutrient agar (NA), potato dextrose agar (PDA) and starch ammonia (SA) medium were used for enumeration of bacteria, fungi and actinobacteria respectively. The results are expressed as Colonial Forming Units CFUs $\mathrm{g}-{ }^{1}$, for fungi $\mathrm{x} 10^{3}$, bacteria $\mathrm{x}$ $10^{6}$, actinobacteria $\times 10^{4}$ (Alexander 1982).

The plates for fungus and actinobacteria are incubated at $25-30^{\circ} \mathrm{C}$, for bacteria at $37^{\circ} \mathrm{C}$, and the populations of bacteria, fungi and actinobacteria were observed at
2, 5 and 7 days after inoculation, respectively.

Was used analysis of variance and significant differences were analyzed using multiple comparison of means of LSD by test of Fischer ranges $(\mathrm{P} \leq 0.05)$ applying InfoStat statistical software 2010 version (Di Rienzo et al. 2010).

\section{Results and discussion}

The influence of land use patterns and distances from the root surface on the total soil fungi, bacteria and actinobacteria counts are presented in Figure 3 and Table 1. Figure 3 and Table 1 showed that population of bacteria, fungi and actinobacteria were decreased as distances from the root surface increased in all land use patterns. Figure 3 also showed that soil microbial population in the rice monoculture T2 and pineapple monoculture T3 were negatively affected. Following the description of the results by type of soil microorganism investigated.

Table 1. Effect of interactions of land use types and soil management factors ${ }^{\star}$ distance from the root surface on the population of bacteria, fungi and actinobacteria.

\begin{tabular}{|c|c|c|c|c|}
\hline \multirow{2}{*}{ Treatments } & \multirow{2}{*}{$\begin{array}{l}\text { Distance from } \\
\text { the root surface }\end{array}$} & \multicolumn{3}{|c|}{ Population (CFU g-1 ${ }^{1}$ soil) } \\
\hline & & Fungi $\left(\times 10^{3}\right)$ & Bacteria $\left(\times 10^{6}\right)$ & $\begin{array}{c}\text { Actinobacteria } \\
\left(\times 10^{4}\right)\end{array}$ \\
\hline \multirow[t]{5}{*}{$\mathrm{T} 1^{1}$} & $\mathrm{D} 1^{5}$ & $49.2^{\mathrm{a}}$ & $286.3^{\mathrm{a}}$ & $97.3^{\mathrm{a}}$ \\
\hline & $\mathrm{D} 2^{6}$ & $32.1^{\mathrm{b}}$ & $231.3^{\mathrm{b}}$ & $84.0^{\mathrm{bc}}$ \\
\hline & $\mathrm{D} 3^{7}$ & $28.3^{\mathrm{b}}$ & $209.3^{\mathrm{b}}$ & $65.0^{\text {ef }}$ \\
\hline & $\mathrm{D} 4^{8}$ & $13.5^{\text {cde }}$ & $171.0^{c}$ & $58.0^{\mathrm{fg}}$ \\
\hline & $\mathrm{D} 5^{9}$ & $13.8^{\text {cde }}$ & $164.6^{\mathrm{cd}}$ & $52.0^{\mathrm{g}}$ \\
\hline \multirow[t]{5}{*}{$\mathrm{T} 2^{2}$} & D1 & $9.7^{\mathrm{def}}$ & $61.6^{\mathrm{f}}$ & $28.3^{\mathrm{h}}$ \\
\hline & D2 & $8.7^{\mathrm{efg}}$ & $56.0^{\mathrm{f}}$ & $22.6^{\mathrm{hi}}$ \\
\hline & D3 & $5.7^{\mathrm{fgh}}$ & $48.6^{\mathrm{f}}$ & $18.6^{\text {hij }}$ \\
\hline & $\mathrm{D} 4$ & $5.2^{\mathrm{fgh}}$ & $45.6^{\mathrm{f}}$ & $13.6^{\mathrm{ijk}}$ \\
\hline & D5 & $3.9^{\mathrm{fgh}}$ & $37.0^{\mathrm{fg}}$ & $11.3^{\mathrm{jk}}$ \\
\hline
\end{tabular}


Cont. Table 1. Effect of interactions of land use types and soil management factors ${ }^{\star}$ distance from the root surface on the population of bacteria, fungi and actinobacteria.

\begin{tabular}{|c|c|c|c|c|}
\hline \multirow{2}{*}{ Treatments } & \multirow{2}{*}{$\begin{array}{l}\text { Distance from } \\
\text { the root surface }\end{array}$} & \multicolumn{3}{|c|}{ Population (CFU g-1 ${ }^{1}$ soil) } \\
\hline & & Fungi $\left(\times 10^{3}\right)$ & Bacteria $\left(\times 10^{6}\right)$ & $\begin{array}{c}\text { Actinobacteria } \\
\left(\times 10^{4}\right)\end{array}$ \\
\hline \multirow[t]{5}{*}{$\mathrm{T}^{3}$} & D1 & $4.2^{\mathrm{fgh}}$ & $13.0^{\mathrm{gh}}$ & $12.0^{\mathrm{ijk}}$ \\
\hline & $\mathrm{D} 2$ & $2.2^{\mathrm{gh}}$ & $9.3^{\text {gh }}$ & $8.0^{\mathrm{jk}}$ \\
\hline & D3 & $1.0^{\mathrm{h}}$ & $8.0^{\mathrm{gh}}$ & $7.6^{\mathrm{jk}}$ \\
\hline & D4 & $0.8^{\mathrm{h}}$ & $7.1^{\mathrm{gh}}$ & $6.3^{\mathrm{k}}$ \\
\hline & D5 & $0.6^{\mathrm{h}}$ & $4.9^{h}$ & $3.0^{\mathrm{k}}$ \\
\hline \multirow[t]{5}{*}{$\mathrm{T} 4^{4}$} & D1 & $19.6^{\mathrm{c}}$ & $155.3^{\mathrm{cd}}$ & $94.0^{\mathrm{ab}}$ \\
\hline & D2 & $19.6^{c}$ & $133.6^{\text {de }}$ & $78.0^{\mathrm{cd}}$ \\
\hline & D3 & $18.3^{\mathrm{c}}$ & $123.0^{\mathrm{e}}$ & $69.6^{\mathrm{de}}$ \\
\hline & D4 & $17.3^{\mathrm{c}}$ & $112.0^{\mathrm{e}}$ & $62.6^{\mathrm{efg}}$ \\
\hline & D5 & $16.6^{\mathrm{cd}}$ & $108.0^{\mathrm{e}}$ & $55.3^{\mathrm{fg}}$ \\
\hline
\end{tabular}

Land use types: ${ }^{1} \mathrm{~T} 1=$ secondary forest; ${ }^{2} \mathrm{~T} 2=$ rice monoculture; ${ }^{3} \mathrm{~T} 3=$ pineapple monoculture and ${ }^{4} \mathrm{~T} 4=$ agroforestry system of Theobroma cacao associated with Acacia mangium. Distances from the root surface:
${ }^{5} \mathrm{D} 1: 0-10 \mathrm{~cm},{ }^{6} \mathrm{D} 2: 10-20 \mathrm{~cm},{ }^{7} \mathrm{D} 3: 20-30 \mathrm{~cm},{ }^{8} \mathrm{D} 4:$ 30-40 cm, ${ }^{9} \mathrm{D} 5: 40-50 \mathrm{~cm}$ of each land use types. In column, mean followed by common letters do not differ significantly at $5 \%$ level by LSD.

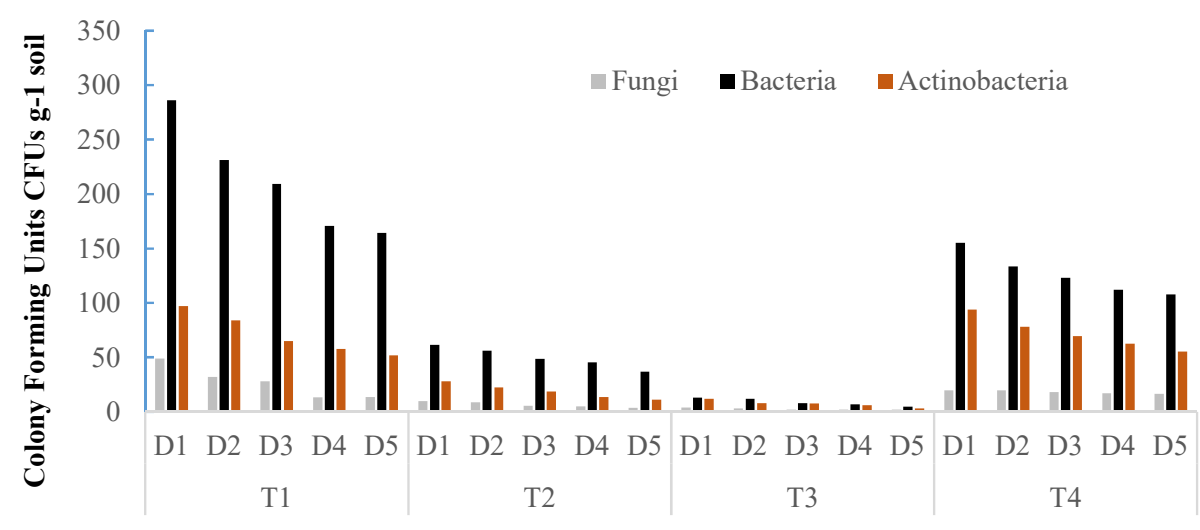

Land use patterns and distances from the root surface

Figure 3. Influence of different land use type and distance from the root surface on microbial population: Fungi x $10^{3}$; bacteria $\times 10^{6}$; actinobacteria $\times 10^{4} \mathrm{CFU} \mathrm{g}^{-1}$ soil. Land use types: $\mathrm{T} 1=$ secondary forest; $\mathrm{T} 2=$ rice monoculture; $\mathrm{T} 3=$ pineapple monoculture and T4= agroforestry system of Theobroma cacao associated with Acacia mangium. Distances from the root surface: D1: 0-10 cm, D2: 10-20 cm, D3: 20-30 cm, D4: 30-40 cm, D5: 40-50 cm of each land use types. 


\section{Fungal population}

High rates of fungal number of CFUs are related to secondary forest $\mathrm{T} 1$ at $0-10 \mathrm{~cm}$ from the root surface D1 (49.23 $\times 10^{3} \mathrm{CFU} \mathrm{g-}^{1}$ soil), compared to pineapple monoculture T3 at $40-50 \mathrm{~cm}$ from the root surface D5 $\left(0.61 \times 10^{3} \mathrm{CFU}\right.$ g-1 soil) $(\mathrm{P} \leq 0.05)$ (Table 1 , Figure $3)$. Fungal population are relatively more abundant in forest than agricultural soils as monocultures (Lauber et al.2013), because carbon products secreted by trees roots, which are preferential nutrients and energy for fungal metabolism.

Secondary forest $\mathrm{T} 1$ at $10-20 \mathrm{~cm}$ from the root surface D2 is associated with moderate increases of the CFUs of fungi $\left(32.1 \times 10^{3} \mathrm{CFU} \mathrm{g-}^{1} \mathrm{soil}^{2}\right.$, which was equal to secondary forest $\mathrm{T} 1$ at $20-30 \mathrm{~cm}$ from the root surface D3 $\left(28.3 \times 10^{3} \mathrm{CFU} \mathrm{g-}^{1}\right.$ soil), indicating that there is a range of best action of fungal populations up to $30 \mathrm{~cm}$ (Table 1, Figure 3). The reduction in fungal population may be explained by secondary forest $\mathrm{T} 1$ at $30-40 \mathrm{~cm}$ from the root surface D4 at $40-50 \mathrm{~cm}$ from the root surface D5 $\left(13.5,13.8 \times 10^{3} \mathrm{CFU} \mathrm{g-}^{1}\right.$ soil) $(\mathrm{P} \geq 0.05)$ (Table 1, Figure 3). The stimulatory effect on microorganisms is known as the "rhizosphere effect" as indicated by the interaction of soil and rhizosphere microbes and their ratio (Paul and Clark 1996).

This indicates that secondary forest $\mathrm{T} 1$, affected positively fungal population in the area closest to the roots directly by generating inputs of organic matter above and belowground and indirectly by the physical effects of shading, soil protection and uptake of water and nutrients by roots (Smith 2008, Lauber et al. 2013, Voř́šková and Baldrian 2013). Forest from natural regeneration may show higher resistance to microclimatic site conditions, which can also contribute to their growth and litter yields, which favors increases in soil microbiota (Notaro et al. 2008). The microbial community in forest soil is dominated by fungi. Fungi are more efficient than bacteria, in terms of decomposing organic compounds (Sylvia et al. 2005).

Rice monoculture T2 and pineapple monoculture T3 exhibiting both conventional tillage and low inputs from residues, as the distances increased of D1 to D5 from the root surface had detrimental effects on fungal number of the CFUs accounting 9.7, 8.7, 5.7, 4.2, 3.9 $\times 10^{3} \mathrm{CFU} \mathrm{g-}^{1}$ soil and 4.2, 2.2, 1.0, 0.8 and $0.6 \times 10^{3}$ CFU g- ${ }^{1}$ soil respectively ( $\left.\mathrm{P} \geq 0.05\right)$ (Table 1, Figure 3 ).

In a study of an Oxisol of the Eastern Plains of Colombia, a leguminous cover with $C$. ochroleuca in rice and corn crops increased by $86 \%$ the greater diversity of fungi, mainly Aspergillus, Cladosporium, Trichoderma and Penicillium (Delgado et al. 2009), which have been reported as phosphate solubilizing microorganisms (Perez et al. 2005), of great importance in phosphorus deficient soils in tropical zones.

Low increment of fungal number of CUFs for pineapple monoculture $\mathrm{T} 3$ at $40-50 \mathrm{~cm}$ from the root surface D5 are due to that monoculture cropping systems and intensive soil management can markedly affect the activity of soil microorganisms and their diversity (Balota et al. 2003), around $89 \%$ decline in microbial diversity index is observed from the distance closest to the rhizosphere to the most distanced (Kent and Triplett 2002).

Contrary to what is stated, other authors say that plant roots do not alter and enhance the total count of the CFUs of fungi in the rhizosphere, in contrast to their effects on bacteria (Whipps 2001, Kent and Triplett 2002).

The chemical and physical nature of the root zone is quite different from the soil away from the root zone, being that fungi population are more likely to regulate decomposition of surface-applied residues in no-till soils in the area adjacent to the root (Paul and Clark 1996, Beare 1997).

The rhizosphere is also a metabolically busier and more competitive environment than the surrounding soil, also known as bulk soil. Unlike the soil associated with the rhizosphere, bulk soil is not penetrated by plant roots and typically have lower microbial communities within it (Kent and Triplett 2002), corroborating this result.

The management of agroforestry system of Theobroma cacao associated with Acacia mangium T4 may provide 
advantages for soil microbiota, due to that all distances from the root surface, which steadily increased from D5 to D1 from the root surface accounting for 16.6, 17.3, 18.3, 19.6 and $19.6 \times 10^{3} \mathrm{CFU} \mathrm{g-}^{1}$ soil (Table 1, Figure 3), was significant similar that the number de CFUs of fungi in secondary forest $\mathrm{T} 1$ at $\mathrm{D} 4$ and D5 distances from the root surface $\left(13.5,13.8 \times 10^{3}\right.$ CFU g- $\left.{ }^{1}\right)(\mathrm{P}>0.05)$, respectively (Table 1, Figure 3$)$. According to Wagg et al. (2014), the function and structure of agroforestry systems may have a similar biological performance that secondary forest. Similarly, Beare (1997) states that this behavior is characteristic of microbial populations in both mature ecosystems and those in process of succession.

Acacia mangium is a leguminous plant that can to be use associated with Theobroma cacao in tropical zones, since it contributes a great amount of litter to the soil, most of the nitrogen is recycled into the soil (Beare 1997).

It is found that surface residues in agroforestry systems retain moisture, dampen temperature fluctuations, and provide a continuous substrate that promotes fungal growth (Beare 1997); trees roots in agroforestry systems exude amino acids and sugars that serve as a food source for microorganisms, since fungi population are poor degraders of cellulose and other plant wall material (Pii et al. 2016), and this is the reason for the high increments of CFUs of fungi.

\section{Bacterial population}

A greater rhizosphere effect was observed in bacteria than actinobacteria and fungi in all land use patterns (Figure 3), due to those bacteria known as plant growth promoting rhizobacteria (PGPR) colonize roots very efficiently (Kent and Triplett 2002, Sylvia et al. 2005).

The population of bacteria ranged from 286.33 to 4.99 $\times 10^{6} \mathrm{CFU} \mathrm{g-}^{1}$ soil corresponding to secondary forest $\mathrm{T} 1$ at $0-10 \mathrm{~cm}$ from the root surface D1 and pineapple monoculture $\mathrm{T} 3$ at $40-50 \mathrm{~cm}$ from the root surface D5, respectively $(\mathrm{P} \leq 0.05)$ (Table 1 , Figure 3$)$. This last treatment showed similar amount to the average of the values reported by Muhammed et al. (2015) for humid tropical climate in Indian for an okra monoculture at fruiting $\left(6.3 \times 10^{6} \mathrm{CFU} \mathrm{g-}^{1}\right.$ soil).

Higher count of bacteria was observed in secondary forest $\mathrm{T} 1$ and all the distances from the root surface compared to others treatments $(p \leq 0.05)$, the number of CFUs of bacteria no reflected a positive response of the increases of the distances of D1 to D5 from the root surface accounting for 286.3, 231.3, 209.3, 171.0 and $164.6 \times 10^{6} \mathrm{CFU} \mathrm{g-}^{1}$ soil respectively (Table 1 , Figure 3).

The bacterial population cover about $4-10 \%$ of the total root area occurring profusely on the root hair region and rarely in the root tips. There is predominance of amino acids and growth factors required by bacteria, are readily provided by the root exudates in the region of rhizosphere (Kent and Triplett 2002). The most common genera of soil bacterias are: Pseudomonas, Arthrobacter, Agrobacterium, Alcaligenes, Azotobacter, Mycobacterium, Flavobacter, Cellulomonas, Micrococcus, and others have been reported to be either abundant or sparse in the rhizosphere (Whipps 2001).

According to Whipps (2001), the aerobic bacteria are relatively less in the rhizosphere because of the reduced oxygen levels due to root respiration.

Other authors as Kent and Triplett (2002) argue that in addition to the respiration of the roots themselves, the carbon-rich environment of the rhizosphere promotes high levels of respiration by other macro and microorganisms, to a far greater extent than what is occurring in the bulk soil.

In contrast, secondary forest $\mathrm{T} 1$ at $30-40 \mathrm{~cm}$ from the root surface D4 and at $40-50 \mathrm{~cm}$ from the root surface D5 (171.0 and $164.6 \times 106 \mathrm{CFU}$ g- 1 soil) was equal that agroforestry system T4 at $0-10 \mathrm{~cm}$ from the root surface $\left(155.3 \times 10^{6} \mathrm{CFU} \mathrm{g-}^{1}\right)$ and at $40-50 \mathrm{~cm}$ from the root surface D5 $\left(133.6 \times 10^{6} \mathrm{CFU} \mathrm{g}^{-1}\right.$ soil) (Table 1, Figure 3).

According Da C Jesus et al. (2009) agroforestry communities are related to intermediate values of the soil biology attributes and crop and young secondary 
forest communities do not constitute well-defined groups.

The values of counts of bacterial UCFs in rice monoculture $\mathrm{T} 2$ at all distances are slightly below average for secondary forests (T1) accounting for 61.6, 56.0, 48.6, 45.6 and $37.0 \times 10^{6} \mathrm{CFU} \mathrm{g-}^{1}$ soil, being statistically differences $(\mathrm{P} \leq 0.05)$ (Table 1 , Figure 3 ) and above average for pineapple monoculture (T3) at all distances, but with no statistically significant differences between rice monoculture T2 at $40-50 \mathrm{~cm}$ from the root surface $\mathrm{D} 5$ and pineapple monoculture $\mathrm{T} 3$ at $10-20 \mathrm{~cm}$ from the root surface $\mathrm{D} 5(\mathrm{P} \geq 0.05)$ (Table 1, Figure 3) $(\mathrm{P} \leq 0.05)$.

According to Beare (1997) plant residue is distributed throughout the plough layer in fields managed with conventional tillage, these soils are dominated by bacteria and their predators such as bacterial-feeding nematodes and are considered to be in an early stage of succession, may possibly explain this response obtained. Gopalakrishnan et al. (2009) also reported the inhibitory effect of root exudates on bacteria.

Bacterial populations have their lowest value when pineapple monoculture $\mathrm{T} 3$ at $40-50 \mathrm{~cm}$ distance maximal from the root surface D5 accounting for 4.9 $\times 10^{6} \mathrm{CFU} \mathrm{g-}^{1}$ soil (Table 1, Figure 3). On the other hand, pineapple monoculture (T3) at all distances from the root surface presented the least count of CFUs of bacteria with no statistically significant differences between these $(\mathrm{P} \geq 0.05)$ responsible for 13.0, 9.3, 8.0, 7.1 and $4.9 \times 10^{6} \mathrm{CFU} \mathrm{g}^{-1}$ soil (Table 1, Figure 3 ).

The magnitude of these responses indicates the need to intensify the studies involving monoculture management and its relation with soil microbiota bioactivity and mechanisms of interaction with root surface.

\section{Actinobacteria population}

The population of actinobacteria ranged from $97.33 \times 10^{4} \mathrm{CFU} \mathrm{g-}^{1}$ soil to $3.00 \times 10^{4}$ soil $\mathrm{CFU} \mathrm{g}^{-1}$ corresponding to secondary forest $\mathrm{T} 1$ at $0-10 \mathrm{~cm}$ from the root surface and pineapple crop T3 at 40-50 $\mathrm{cm}$ from the root surface D5 revealed statistically significant differences $(\mathrm{P} \leq 0.05)$ (Table 1, Figure 3$)$.

Higher actinobacteria population was recorded for T1 at $0-10 \mathrm{~cm}$ from the root surface D1 $\left(97.3 \times 10^{4} \mathrm{CFU} \mathrm{g-}{ }^{1}\right.$ soil) followed by T4 at $\mathrm{D} 1\left(94.0 \times 10^{4} \mathrm{CFU} \mathrm{g}^{-1}\right.$ soil $)$ and $\mathrm{T} 1$ at D2 $\left(78.0 \times 10^{4} \mathrm{CFU} \mathrm{g-}{ }^{1}\right.$ soil), in turn this treatment equaled to T4 at D3 $\left(69.6 \times 10^{4} \mathrm{CFU} \mathrm{g}^{-1}\right.$ soil), being that secondary forest $\mathrm{T} 1$ and agroforestry system $\mathrm{T} 4$ by effect of all distances from the root surface showed similarity in actinobacteria population $(\mathrm{P} \geq 0.05)$ (Table 1, Figure 3).

Soil community composition with agroforestry systems resembles that of natural ecosystem soils more closely than in the case with annual crops (Brussaard et al. 2007). Among different microbial population, the bacterial population was recorded maximum (64\%), followed by actinobacteria (23\%) and fungi $(13 \%)$ in agroforestry systems (Radhakrishnan and Varadharajan 2016).

The populations of soil microbiota found in the Leucaena plantation were generally similar to the Atlantic forest and higher than in the Corymbia plantation (Reis et al. 2007).

Stimulation of actinobacteria in the rhizosphere has not been studied in much detail so far. It is generally understood that the actinobacteria are less stimulated in the rhizosphere than bacteria. However, when antagonistic actinobacteria increase in number they suppress bacteria (Wagg et al. 2014).

The actinobacteria population was reduced drastically by effect of rice monoculture $\mathrm{T} 2$ and pineapple monoculture $\mathrm{T} 3$ at all the distances from the root surface accounting for 28.3, 22.6, 18.6, 13.6, 11.3 and 12.0, 8.0, 7.6, 6.3, $3.0 \times 10^{4} \mathrm{CFU} \mathrm{g-}^{-1}$ soil respectively, revealed no statistically significant differences between these $(\mathrm{P} \geq 0.05)$ (Table 1, Figure 3). The root endosphere microbiota results from gradual community shifts including enrichment and depletion processes from the surrounding soil microbiota (Sylvia et al. 2005; Barreto et al. 2008). 
As rice and pineapple monocultures and soil management practices influenced soil actinobacteria populations at all distances from the root surface, it is important to propitiate the effect of soil microbiota enrichment process begin acting at a distance in the rhizosphere, continues at the rhizoplane, and is largely driven by root exudation, through efficient practices of soil management such as direct seeding and crop rotation. Difference in microbial population is a reflection of many factors such as nutrient and oxygen levels, temperature and availability of minerals (Sylvia et al. 2005).

\section{Conclusions}

The positive relation of fungi, bacteria and actinobacteria organisms with secondary forest (T1) at all distances from the root surface, is important for the establishment of the natural vegetation in tropical zones of Villavicencio, East Colombia.

The negative impact of rice monoculture (T2) and pineapple monoculture (T3) at all distances from the root surface on Oxisol microbiota disturbance, suggest that it should be taken in consideration for more sustainable soil management factors that contribute great amount of soil organic matter in monocultures systems.

The soil microbiota comparison in land use patterns and distances from the root surface revealed that agroforestry system of Teobroma cacao associated with Acacia mangium (T4) have potential to increase fungi, bacteria and actinobacteria in a tropical Oxisol of Villavicencio.

\section{References}

Alexander, M. 1982. Most Probable Number method for microbial populations. Pp. 815-820. En: Page, A. L., R. H. Miller and D. R. Keeney (Eds). Methods in Soil Analysis. Agronomy 9, part $2,2^{\text {nd }}$ edition. ASA, SSSA, Madson, WI.

Alvear, M. A., J. L. Rosas and F. B. Rouanet. 2005. Effects of three soil tillage systems on some biological activities in an Ultisol from southern Chile. Soil and Tillage Research 82: 195-202.

Balota, E. L., A. Colozzi-Filho, D. S. Andrade and R. P. Dick. 2003. Microbial biomass in soils under different tillage and crop rotation systems. Biology and Fertility of Soils 38 (1): 15-20.
Barreto, T. R., A. C. M. Da Silva, A. C. F. Soares and J. T. De Souza. 2008. Population densities and genetic diversity of actinomycetes associated to the rhizosphere of Theobroma cacao. Brazilian Journal of Microbiology 39 (3): 464-470.

Barrios, E. 2007. Soil biota, ecosystem services and land productivity. Ecological economics 64: 269-285

Bausenwein, U., A. Gattinger, U. Langer, A. Embcher, H. P. Hartmann, M. Sommer, J. C. Munch and M. Schloter. 2008. Exploring soil microbial communities and soil organic matter: Variability and interactions in arable soils under minimum tillage practice. Applied soil ecology 40: 67-77.

Beare, M. H. 1997. Fungal and bacterial pathways of organic matter decomposition and nitrogen mineralization in arable soil. Pp 37-70. En: Brussaard, L. and R. Ferrera- Cerrato (Eds). Soil Ecology in Sustainable Agricultural Systems. Lewis Publishers, Boca Raton, LA.

Brussaard, L., P. C. de Ruiter, G. G. Brown. 2007. Soil biodiversity for agricultural sustainability. Agriculture, Ecosystems and Environment 121: 233-244.

Ceja-Navarro, J. A., F. N. Rivera-Orduña, L. Patiño- Zúñiga, A. Vila-Sanjurjo, J. Crossa, B. Govaerts and L. Dendooven. 2010. Phylogenetic and multivariate analyses to determine the effects of different tillage and residue management practices on soil bacterial communities. Applied and Environmental Microbiology 76 (11): 3685-3691.

Da C Jesus, E., T. Marsh, J. Tiedje and F. Moreira. 2009. Changes in land use alter the structure of bacterial communities in Western Amazon soils. The International Society for Microbial Ecology Journal 3: 1004-1011

Delgado, H., G. H. Navas, C. R. Salamanca and A. Chacon. 2009. Legume improved fallows: a promissory agroecological alternative for allelopathic weed control in rice and maize crops in the Colombia Eastern Plains Agronomia Colombiana 27 (2): 227-235.

Di Rienzo, J. A., F. Casanoves, M. G. Balzarini, L. González, C. W. Robledo. 2010. InfoStat versión 2010. Grupo InfoStat, FCA, Universidad Nacional de Córdoba, Argentina. 18 p.

Gopalakrishnan, S., T. Watanabe, S. J. Pearse, O. Ito, Z. A. K. M. Hossain and G. V. Subbarao. 2009. Biological nitrification inhibition by Brachiaria humidicola roots varies with soil type and inhibits nitrifying bacteria, but not other major soil microorganisms. Soil Science Plant Nutrition 55 (5): 725-733.

Instituto Geográfico Agustín Codazzi - Igac. 2004. Estudio general de suelos y zonificación de tierras. Departamento del Meta. IGAC. $1 \mathrm{CD}$.

Jangid, K., M. A. Williams, A. J. Franzluebbers, J. S. Sanderlin, J. H. Reeves, M. B. Jenkins, D. M. Endale, D. C. Coleman and W. B. Whitman. 2008. Relative impacts of land-use, management intensity and fertilization upon soil microbial community structure in agricultural systems. Soil Biology Biochemestry 40: 2843-2853.

Kent, A. D. and E. W. Triplett. 2002. Microbial communities and their interactions in soil and rhizosphere ecosystems. Annual Review of Microbiology 56: 211-236.

Lauber, C. L., K. S. Ramirez, Z. Aanderud, J. Lennon and N. Fierer. 2013. Temporal variability in soil microbial communities across land-use types. International Society for Microbial Ecology 7: 1641-1650. 
Mathew, R. P., Y. Feng, L. Githinji, R. Ankumah and K. S. Balkcom. 2012. Impact of No-tillage and conventional tillage on soil microbial communities. Applied Environmental Soil Science: $10 \mathrm{p}$.

Muhammed, U. P. F. B., P. V. Sindhu and K. S. Gopal. 2015. Influence of mulches on rhizosphere microflora, yield and weed competition in okra (Abelmoschus esculentus (L.) Moench). Journal of Tropical Agriculture 53 (1): 70-74.

Notaro, K., E. V. de Medeiros, G. P. Duda, A. O. Silva. and P. M. De Moura. 2008. Agroforestry systems, nutrients in litter and microbial activity in soils cultivated with coffee at high altitude. Scientia Agricola 71 (2): 87-95.

Paudel, B. R., R. P. Udawatta, R. J. Kremer and S. H. Anderson. 2012. Soil quality indicator responses to row crop, grazed pasture, and agroforestry buffer management. Agroforestry Systems 84: 311-323.

Paul, E. A. and F. E. Clark. 1996. Soil Microbiology and Biochemistry, Academic Press, San Diego, California, USA. $340 \mathrm{p}$.

Perez, A., C. Perez y G. Cardona. 2015. Hongos solubilizadores de fosfatos en suelos arroceros de la Mojana Sucre, Colombia. Arroz 53 (458): 22-31.

Pii, Y., L. Borruso, L. Brusetti, C. Crecchio, S. Cesco and T. Mimmo. 2016. The interaction between iron nutrition, plant species and soil type shapes the rhizosphere microbiome. Plant Physiology and Biochemistry 99: 39-48.

Prevost-Boure, N. C., P. A. Maron, L. Ranjard, V. Nowak, E. Dufrenea, C. Damesina, K. Soudani and J-Ch. Lata. 2011. Seasonal dynamics of the bacterial community in forest soils under different quantities of leaf litter. Applied Soil Ecology 47 (1): $14-23$

\author{
Amanda Silva-Parra \\ Facultad de Ciencias Agropecuarias y Recursos Naturales, \\ Grupo de Investigación ISAF \\ Universidad de los Llanos, Sede Barcelona, Colombia \\ Km. 12 vía Puerto López \\ asilvap@unillanos.edu.co \\ Ángela María Mogollón-Ortiz \\ Facultad de Ciencias Agropecuarias y Recursos Naturales, \\ Grupo de Investigación ISAF \\ Universidad de los Llanos, Sede Barcelona, Colombia \\ Km. 12 vía Puerto López \\ amogollon@unillanos.edu.co

\section{Hernando Delgado-Huertas} \\ Facultad de Ciencias Agropecuarias y Recursos Naturales, \\ Grupo de Investigación ISAF \\ Universidad de los Llanos, Sede Barcelona, Colombia \\ Km. 12 vía Puerto López \\ hdelgado@unillanos.edu.co
}

Radhakrishnan, S. and M. J. Varadharajan. 2016. Status of microbial diversity in agroforestry systems in Tamil Nadu, India. Journal of Basic Microbiology 56 (6): 662- 669.

Reis, M. A., K. Luciene, A. M. Rodrigues and E. Nahas. 2007. Recovery of soil microbiological properties in a degraded area planted with Corymbia citriodora and Leucaena leucocephala. Scientia Agricola 64 (1): 8-72.

Roger-Estrade, J., C. Anger, M. Bertrand and G. Richard. 2010. Tillage and soil ecology: Partners for sustainable agriculture. Soil and Tillage Research 111: 33-40.

Sylvia, D., J. Fuhrmann, P. Hartel and D. Zuberer. 2005. Principles and Applications of Soil Microbiology. Pearson Education Inc. New Jersey. 517 p.

Smith, P. 2008. Land use change and soil organic carbon dynamics. Nutrient Cycle Agroecosystem 81: 169-178.

Voříšková, J. and P. Baldrian. 2013. Fungal community on decomposing leaf litter undergoes rapid successional changes. International Society for Microbial Ecology Journal 7: 477-486.

Wagg, C., S. F. Bender, F. Widmer and M. G. A. Van der Heijden. 2014. Soil biodiversity and soil community composition determine ecosystem multifunctionality. Proceedings of the National Academy of Sciences of the United States of America 111: 5266-5270.

Whipps, J. M. 2001. Microbial interactions and biocontrol in the rhizosphere. The Journal of Experimental Botany 52 (90001): 487-511.

Soil microbiota: Influence of different land use patterns and soil management factors at Villavicencio Oxisol, East Colombia

Citación del artículo: Silva-Parra, A, A. M. Mogollón-Ortiz y H. Delgado-Huertas. 2017. Soil microbiota: Influence of different land use patterns and soil management factors at Villavicencio Oxisol, East Colombia. Biota Colombiana 18 (2): 1 - 10. DOI: 10.21068/c2017.v18n02a1

Recibido: 02 de diciembre de 2016 Aprobado: 23 de mayo de 2017 